\title{
DETERMINATION OF THE FLOW PROPERTIES AT DYE 3, SOUTH GREENLAND, BY BORE-HOLE-TILTING MEASUREMENTS AND PERTURBATION MODELLING
}

\author{
By DORTHE DAHL-JENSEN \\ (Geophysical Institute, Department of Physical Glaciology, University of Copenhagen, Haraldsgade 6, DK-2200 Copenhagen N, \\ Denmark)
}

\begin{abstract}
The ice-flow properties at great depths have a strong impact on the depth-age relationship of the strata in the Greenland ice sheet. Previous attempts to calculate this relaticrishin have used Glen's flow law with a temperature-depcndent flow-law parameter. The data from the bore-hole-tilting at Dye 3, south Greenland, make it possible to calculate the flow-law parameter versus depth. The flow-law parameter shows a big change at the Holocene/Pleistocene transition with a mean flow enhancement factor of 3 for the ice deposited during the last glaciation. This high enhancement factor is believed to be due to high concentrations of dust and other impurities and small ice-crystal size in the Pleistocene ice. The derived flow-law parameter and the up-stream basal topography are used in a two-dimensional, multi-layer, first-order perturbation model to calculate the surface undulations and strain-rates. The results compare favourably with the observations. The results depend strongly on the flow-law parameter profile, which can therefore be estimated in other areas by perturbation-model calculations along flow lines, if the surface and base topographies are known.
\end{abstract}

RÉsumÉ. Détermination des propriété de l'écoulement à Dye 3, Groenland du sud, par mesures d'inclinométrie dans les forages et modélisation des perturbations. Les propriétés du fluage de la glace à grande profondeur ont un fort impact sur la relation profondeur-âge pour la calotte de glace du Groenland. Des essais antérieurs de calcul de cette rclation ont untilisé une loi de fluage de Glen avec un paramétre de fluage dépendant de la température. Les données issues de l'inclinométrie à Dye 3, Groenland du sud, rendent possible un calcul du paramètre de la loi de fluage en fonction de la profondeur. Ce paramètre montre une importante variation lors de la transition Holocène/Pléistocène en triplant sa valeur pour la glace formée au cours de la dernière glaciation. Cette forte augmentation est interprêtée comme étant la conséquence d'importantes concentrations de poussières et autres impuretés, ainsi

\section{INTRODUCTION}

Several authors have treated the relationship between glacier surface and bedrock topographies. Nye (1959) calculated a first approximation using Glen's flow law in a simple way. As more and better data on surface and base profiles became available, perturbation models were developed to explain the small-scale undulations caused by an irregular base. Budd (1970) described a perturbation method for Newtonian viscous media, and Hutter and others (1981) gave a systematic analysis of the governing equations and boundary conditions for first-order perturbation models.

Simplified perturbation models have been applied to several flow lines in areas with known surface and que de la faible taille des cristaux de glace au cours du Pléistocène. La paramètre de la loi d'écoulement ainsi déterminé et la topographie du lit sont utilisés dans un modèle de perturbation du premier ordre à deux dimensions, multi couches pour calculer les ondulations de surface et les taux de déformation. Les résultats sont en bon accord avec les observations. Ils sont très sensibles aux variations due profil du paramètre de la loi de déformation, qui peut cependant être estimé dans d'autres zones par le modèle de perturbations le long des lignes d'écoulement lorsque les topographies en surface et sur le lit sont connues.

ZUSAMMENFASSUNG. Bestimmung der Fliessverhältnisse in Dye 3, Südgrönland, mit Hilfe von Neigungsmessungen in Bohrlöchern und Störungsmodellen. Die Fliessverhältnisse des Eises in grosser Tiefe haben starken Einfluss auf die Beziehung zwischen Tiefe und Alter der Eisschichten im grönländischen Inlandeis. Frühere Versuche zur Berechnung dieser Beziehung benutzten das Glen'sche Fliessgesetz mit einem temperaturabăngigen Parameter. Die Daten der Bohrlochneigungen tei Dye 3 in Südgrönland ermöglichen eine Berechnung des Fliessgesetzparameters in der Tiefe. Dieser weist eine grosse Änderung am Übergang zwischen Holozăn und Pleistozăn auf, wobei der mittlere Fluss für das während der letzten Vereisung abgelagerte Eis um den Faktor 3 vergrössert erscheint. Ein derartiger Anstieg wird auf die hohen Konzentrationen von Staub und anderen Verunreinigungen sowie auf die geringe Grösse der Eiskristalle zurückgeführt. Der gewonnene Fliessgesetzparameter und die Topographie des Untergrundes verden in einem zweidimensionalen Vielschichten-Störungsmodell erster Ordnung zur Berechnung der Undulationen und Verformungsraten an der Oberfläche herangezogen. Die Ergebnisse stimmen mit den Beobachtungen überein; sie hăngen stark vom Profil des Fliessgesetzparameters ab, das deshalb in anderen Gebieten aus der Berechnung des Störungsmodells entlang von Stromlinien abgeschătzt werden kann, wenn die Gestalt der Oberfläche und des Untergrundes bekannt ist.

bedrock profiles. Whillans and Johnsen (1983) used a linear viscous flow law to model the Byrd Station, West Antarctica, flow line, Johnsen and others (1979) and Rasmussen (unpublished) introduced a multitayer model with Newtonian viscous flow, which was used by Overgaard and Rasmussen (1979) on the EGIG line, south Greenland. Reeh and others (in press) modelled the flow-line up-stream from Dye 3, south Greenland, using Glen's flow law with a flow taw parameter which varies exponentially with depth to account for changes in stress, temperature, ice fabrics, etc. The predicted Dye 3 surface undulations were $50 \%$ smaller than observed.

In this work, a more realistic flow-law parameter profile along the $2037 \mathrm{~m}$ deep bore hole at Dye 3 will be derived from Gundestrup and Hansen's (1984) 
measurements of the temporal changes of the hole geometry. It will be used in a first-order, multi-layer, two-dimensional perturbation model, and the predicted surface undulations and strain-rates will be compared with observed data (Overgaard and Gundestrup, in press; Whillans and others, 1984).

\section{TOPOGRAPHY AND BORE-HOLE-TILTING DATA}

The Dye 3 bore hole is located at long. $65.19^{\circ} \mathrm{N}$., lat. $43.82^{\circ} \mathrm{W}$., $41.51 \mathrm{~km}$ east of the ice divide (Overgaard and Gundestrup, in press). The base and surface elevations are known (Overgaard and Gundestrup, in press) along three parallel lines (A, B, and C) as shown on Figure 1. Based on surface strain-rates (Whillans and

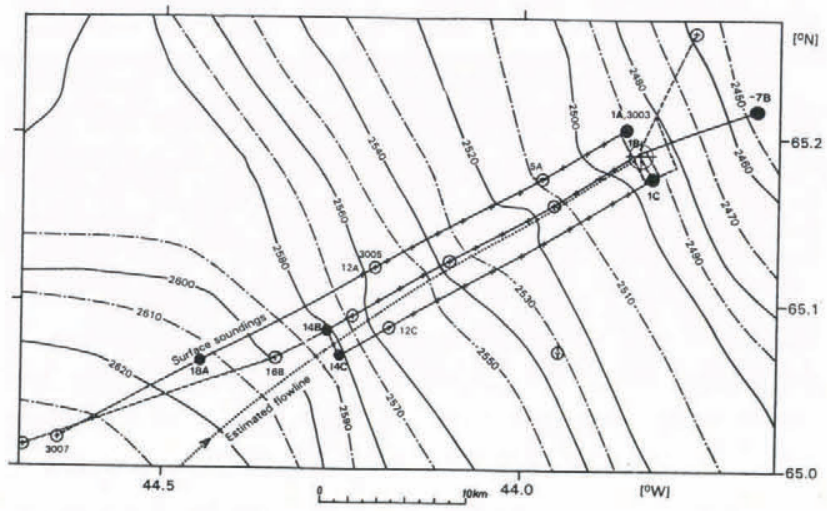

Fig. 1. Surface elevation map of the Dye 3 region (Overgaard and Gundestrup, in press), elevations in metres above seatevel. The Dye 3 drill hole is located at point IB. Basal and surface elevation profiles are measured along the three parallel lines $A, B$, and $C$. The filled circles mark the ends of the line intervals used in the model.

others, 1984) and repeated satellite fixed points (Zwally and others, 1983) the flow line (dotted line on Fig. 1) is estimated. Between 14B and $-7 \mathrm{~B}$ it is close to the B-line. In Figure 2 the surface and base elevations are shown along the $\mathrm{A}, \mathrm{B}$, and $\mathrm{C}$ lines. Obviously, the bedrock topography has undulations of up to $15 \%$ of the ice thickness. The dashed lines in Figure 2 are trend lines; the base trends are determined as the least-square linear fit to the observed base-elevation profiles, the surface trends as a least-square fit to an ice-sheet profile suggested by Nye (1959). The dashed lines in Figure 2 represent the lower and upper boundaries to the basic flow in the perturbation modelling below.

The inclination and azimuth profiles measured by logging of the Dye 3 deep hole in 1981 and 1983 (Gundestrup and Hansen, 1984) give information about the deformation rates of the ice. The horizontal velocity $u(z)$ along the core (where $z$ is the distance above the base) and its vertical gradient $\partial u(z) / \partial z$ were calculated with the assumption of laminar flow (Gundestrup and Hansen, 1984).

$250 \mathrm{~m}$ above bedrock $\partial u / \partial z$ profile shows a sharp transition to much higher deformation rates at greater depths (Fig. 3a). This remarkable shift coincides with the transition between Holocene and Pleistocene ice (Dansgaard and others, 1982). The very highest deformation rates are found in the bottom $25 \mathrm{~m}$ of silty ice. In the upper $1000 \mathrm{~m}$ the inclination changes are too small to allow accurate estimates of $\partial u(z) / \partial z$, but they do show that practically all of the deformation takes place at great depths, and that the flow of the Holocene ice at Dye 3 is essentially block flow.

\section{THE FLOW-LAW PARAMETER}

In order to simplify the calculation of the flow-law parameter, the flow is assumed to be two-dimensional and stationary, and Glen's flow law for isotropic ice (Glen, 1955) is assumed to be valid. If the flow-law exponent is 3, as most results from bore-hole tilting suggest (Paterson, 1981, 1983), the equation for shear deformation is:

$$
\frac{1}{2}\left[\frac{\partial u}{\partial z}+\frac{\partial w}{\partial x}\right]=B\left[\tau_{x z}{ }^{2}+t\left(\sigma_{x}-\sigma_{z}\right)^{2}\right] \tau_{x z},
$$

$u$ and $w$ being the horizontal and vertical velocities, $B$ the flow-law parameter, $\sigma_{x}, \sigma_{z}, T_{x z}$ the stress components, $x$ the axis parallel to the basal trend line, and $z$ the axis perpendicular to the $x$-axis.

Near the bottom of the bore hole the deformation is dominated by shear, which allows the following approximation to Equation (1):

$$
\frac{1}{2} \frac{\partial u}{\partial z}=B r_{x z}{ }^{3} \text {. }
$$

The flow law parameter $B$ is considered to be a function of temperature, ice fabric, ice crystal size, and impurity concentration in the ice.

The shear stress $\boldsymbol{\tau}_{x z}$ is calculated as

$$
T_{x z}=\rho g \sin \alpha_{0}\left(H_{0}-z\right) \text {, }
$$

a)

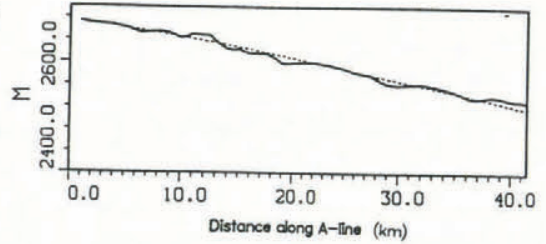

b)

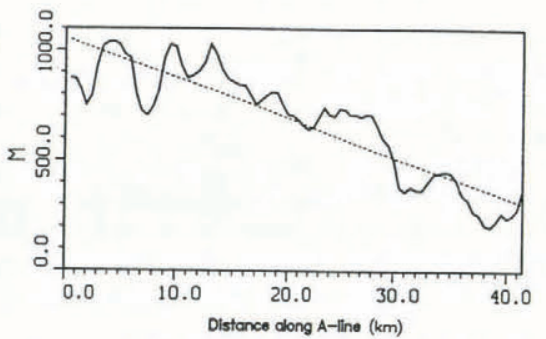

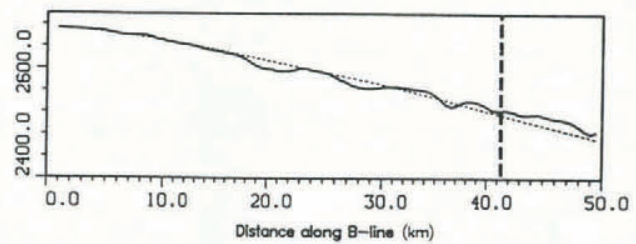
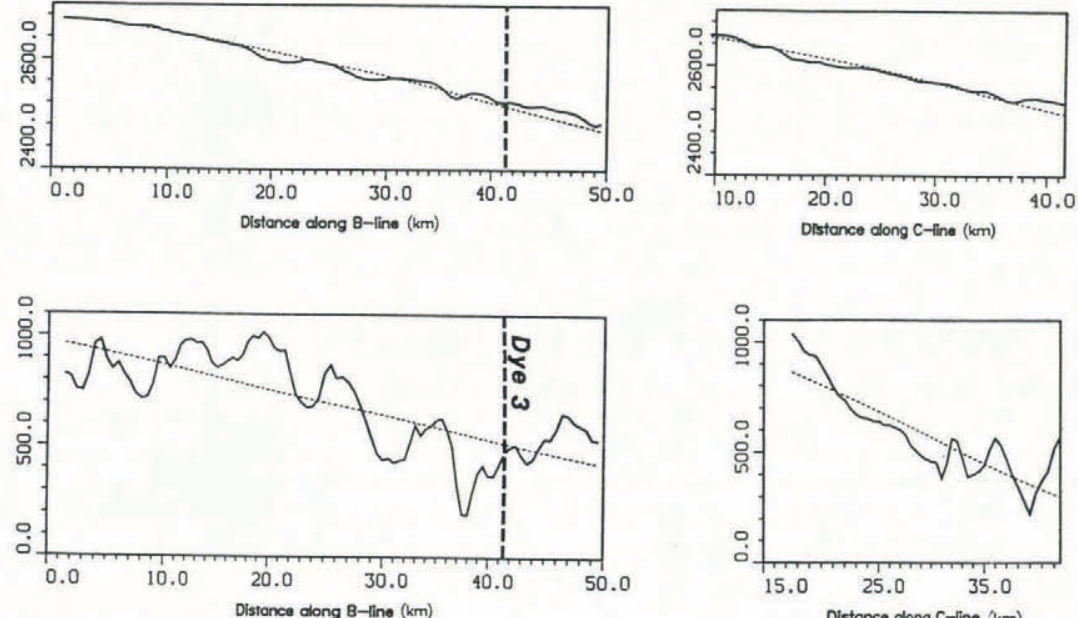

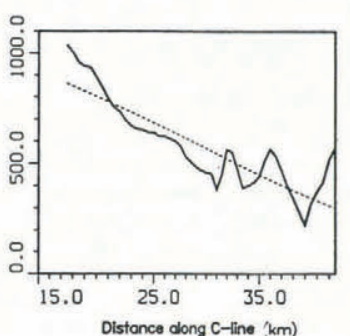

Fig. 2. Surface and basal elevation profiles along the $A, B$, and $C$ lines. The full curves are observed and the dashed curves are trends of the profiles. The $x$-axis shows the distance in kilometres from the interception between the ice crest and the $A, B$, and $C$ lines respectively. Dye 3 is located at $41.5 \mathrm{~km}$ on the B-line. 

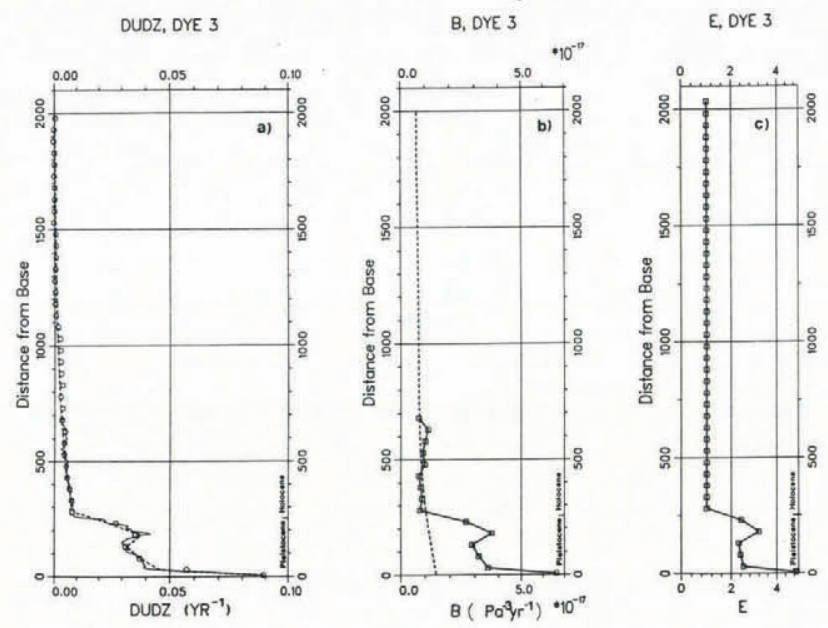

Fig. 3. Flow-law parameters derived from the Dye 3 bore-hole-tilting measurements.

(a) The full curve shows $\mathrm{\partial u} / \mathrm{\partial z}$ for the bottom $700 \mathrm{~m}$, points are the $50 \mathrm{~m}$ averaged $\mathrm{\partial u} / \mathrm{\partial z}$ values and the dashed curve represents values calculated from the model.

(b) The flow-law parameter estimated by Equation (2) for the bottom $700 \mathrm{~m}$ is shown as the full curve. The dashed curve is the best fit to the Arrhenius equation (3). The B-profile used in the model is the full curve for $z \leqslant 250 \mathrm{~m}$ and the dashed curve for $z>250 \mathrm{~m}$.

(c) The enhancement factor $E$. The enhancement factor is the factor of the flow-law parameter $B$ which depends on the impurity concentration, size, etc., in the ice. The enhancement factor does not depend on the ice temperature.

p being the ice density, $g$ the gravitational acceleration, $\alpha_{0}$ the mean surface slope at Dye 3 (averaged over $\left.10 \mathrm{~km}\left(5 H_{\mathrm{o}}\right)\right)$, and $H_{0}$ the mean ice thickness at Dye 3 (averaged over $10 \mathrm{~km}\left(5 \mathrm{H}_{0}\right)$ ).

Perturbation models (Reeh and others, in press) indicate that the simple linear equation (3) gives a satisfactory description of the shear stress at the deep hole, in spite of the mountainous bedrock topography in the area.

The estimate of $\partial u(z) / \partial z$ from the bore-hole tilting and the calculated shear stress $\boldsymbol{T}_{x z}$ from Equation (3) allow calculation of $B$ for the bottom $700 \mathrm{~m}$. The full curve in Figure $3 \mathrm{~b}$ shows the calculated $B$-profile. At the Holocene to Pleistocene transition $(z=250 \mathrm{~m}), B$ increases by a factor of three, in agreement with the experiments of Shoji and Langway (in press), and in the $25 \mathrm{~m}$ of silty ice close to the base, $B$ reaches a level approximately seven times higher than the Holocene value, which is $1.0 \times 10^{-17} \mathrm{~Pa}^{-3}$ year ${ }^{-1}$, in agreement with the flow-law parameter suggested by Paterson (1981). In the Holocene ice, $B$ decreases slowly upwards. These trends will be interpreted below.

As to the Holocene ice, the decreasing temperature upward in the bore hole (Gundestrup and Hansen, 1984), essentially explains the variation of $B$, as can be verified by applying the Arrhenius equation in the interval $250 \mathrm{~m}<z \leqslant 700 \mathrm{~m}$ :

$$
A(T)=A_{0} \exp \left[\frac{-Q}{R T}\right],
$$

$Q$ being the activation energy $(60 \mathrm{~kJ} / \mathrm{mol})$ (Paterson, $1981), R$ the gas constant $\left(8.314 \mathrm{~J} \mathrm{~mol}^{-1} \mathrm{~K}^{-1}\right)$, and $T$ the absolute temperature. The constant $A_{0}$ is calculated to be $9.8 \times 10^{-6} \mathrm{~Pa}^{-3}$ year ${ }^{-1}$ by inserting the measured $B$ and $T$ profiles through the said interval.

In order to explain the Pleistocene $B$-profile, it is practical to divide $B$ into a temperature-dependent factor $A(T)$ and an enhancement factor $E$ that depends on other ice parameters.

$$
B=A(T) E .
$$

According to Equation (4), $E$ equals unity for $250 \mathrm{~m}<z \leqslant 700 \mathrm{~m}$, and this is assumed to hold in all of the Holocene ice $(z>250 \mathrm{~m})$. In the Pleistocene ice $(0<z \leqslant 20 \mathrm{~m}), E$ is calculated using Equation (5) and shown on Figure 3c. This part of the $B$-profile is probably to be explained by varying impurity concentration, crystal size, and ice fabric.

The measurements of ice-crystal size (Herron and others, in press), dust concentration, and pH (Hammer and others, in press) along the deep ice core all give profiles characterized by nearly constant values in the Holocene ice, and different and highly variable values in the Pleistocene ice. The crystal size decreases by a factor of two at the Holocene to Pleistocene transition; the dust concentration increases by one to two orders of magnitude, and the ice becomes alkaline. The shape of the dust concentration profile is very similar to that of the deformation rate $\partial u / \partial z$ profile (Gundestrup and Hansen, 1984).

The single-maximum $c$-axis fabric of the ice crystals intensifies with increasing depth (Herron and others, in press), but it does not change drastically at the said transition to judge from the few measurements available in Pleistocene ice. Hence, the high deformation rates in Pleistocene ice cannot be explained by a $c$-axis alignment. This is why Gundestrup and Hansen (1984) concluded that dust concentration, and possibly other parameters that vary in a similar way, are responsible for the easy flow in Pleistocene ice. It should be mentioned that the enhancement factor defined by Equation (5) agrees with the observed variations of dust, etc., over the entire ice-sheet thickness.

In the perturbation model to be designed below, we also need the longitudinal strain rate $\partial u / \partial x(z)$, which is given by Glen's flow law (Glen, 1955):

$$
\frac{\partial u}{\partial x}=B\left[\tau_{x z}{ }^{2}+\frac{1}{2}\left(\sigma_{x}-\sigma_{z}\right)^{2}\right] \ddagger\left(\sigma_{x}-\sigma_{z}\right) .
$$

Glen's flow law (Equation (1) and (6)) describes the deformation rates of istotropic ice. As the enhancement factor $E$ is assumed to depend on parameters which hardly affect the isotropic properties of the ice, Glen's flow law remains valid and the flow law parameter $B$ in Equation (6) is given by Equation (5).

Observations of the mean-diameter profile in the Dye 3 bore hole (Gundestrup and Hansen, 1984) support these considerations: the slowly increasing diameter with depth is caused by overpressure in the hole fluid since the hole was drilled, but the big diameter increase at the Holocene/Pleistocene ice are features similar to the observed variations of the $\partial u / \partial z$ and dust-concentration profiles. These diameter changes in the Pleistocene ice must result from higher and variable values of the flow law parameter in Equation (6), resulting in a $B$-profile here similar to the $B$-profile in Equation (5).

The enhancement factor $E$ is therefore used to model the softer ice, deposited during the last glaciation, and $E$ is not used to model anisotropic ice.

As a final test on the derived flow-law parameter $B$ (Equation (5)), the $\partial u / \partial z$ profile has been calculated by Equation (1). $\boldsymbol{T}_{x z}$ is calculated by Equation (3), $\partial w / \partial x$ is neglected and the longitudinal stress deviation $\left(\sigma_{x}-\sigma_{z}\right)$
is modelled:

(1) using the horizontal velocity profile $u(z)$ from the bore-hole-tilting measurements,

(2) assuming the profile form of $u(z)$ to be slowly changing in $x$ along the flow line,

(3) using accumulation rates along the flow-line (Reeh and others, in press; Ragle and Davis, 1962).

With these assumptions the left-hand side of Equation (6) $\partial u / \partial x$ is given by:

$$
\frac{\partial u}{\partial x}=\frac{u a}{Q}-\frac{u}{H_{o}} \frac{\mathrm{d} H_{0}}{\mathrm{~d} x}-z \frac{\partial u}{\partial z} \frac{\mathrm{d} H_{0}}{\mathrm{~d} x},
$$


$Q$ being the mass flux determined either by the accumulation rates along the flow line $Q=\int_{0}^{x} \mathrm{a}\left(x^{\prime}\right) \mathrm{d} x^{\prime}$ or by the bore-hole tilting measurements $Q=\int_{0}^{H_{0}} u(z) \mathrm{d} z$.

$\left(\sigma_{x}-\sigma_{z}\right)$ is calculated by inserting Equation (7) into Equation (6).

The calculated $\partial u / \partial z$ profile (Fig. 3a) agrees with that observed within the measuring accuracy.

In principle, the bore-hole-tilting measurements should reveal a possible deformation effect of the increasing single-maximum $c$-axis orientation downward in the Holocene ice. However, this effect must be negligible in the Dye 3 area, because the observed increase of $\partial u / \partial z$ and $B$ downwards are fully explained by $A(T)$ in the Holocene ice.

\section{PERTURBATION MODELLING OF THE ICE DEFORMATION}

The derived flow-law parameter $B$ is used in a stationary, multi-layer, two-dimensional first-order perturbation model, where deformation is determined by Glen's flow law (Equations (1) and (6)). As described above, the basal and surface profiles are divided into smoothed profiles and deviations from these. The flow between the smoothed boundaries is called the basic flow. At Dye 3 the stress fields in the basic flow are assumed to be determined as described above, the horizontal velocity by the bore-hole-tilting measurements and the vertical velocity by integration of Glen's flow law (7) as $\partial w / \partial z=-\partial u / \partial x$.

The aim of the perturbation method is to calculate the perturbations of the basic stresses, velocities, and surface profile caused by the basal undulations. The basal undulations, i.e. deviations from the smoothed basal profiles along the A, B, and C lines (Figs 1 and $6 c)$, will serve as the perturbating input in the perturbation model to be outlined below. The A, B, and $C$ lines used in the analysis are restricted as shown in Figure 1 to regions, where the lines follow flow tines.

The bedrock deviations are resolved in a Fourier series of the form:

$$
R(x)=\sum_{n=1}^{N} R_{n} \cos \left(\omega n x-\Phi_{n}\right),
$$

where $N$ in this analysis is 12

For a first-order model, it is possible to calculate the resulting perturbations of the stresses, velocities, and surface elevation for each wavelength separately. Let us choose the following representation of the base:

$$
R(x)=R_{0}(x)+\epsilon R_{1}(x)=0+\epsilon H_{0} \cos \omega x,
$$

in which it is assumed that $\epsilon \ll 1$. The mean base is given by $R_{0}(x)=0$, because the $x$-axis is parallel to this trend line.

This basal perturbation will change the stresses, velocities, and surface elevation into:

$$
\begin{aligned}
u & =u_{0}+\epsilon u_{1}, \\
w & =w_{0}+\epsilon w_{1}, \\
\sigma_{x} & =\sigma_{x 0}+\epsilon \sigma_{x 1}, \\
\sigma_{z} & =\sigma_{z 0}+\epsilon \sigma_{z 1}, \\
\tau_{x z} & =\tau_{x z 0}+\epsilon \tau_{x z 1}, \\
S(x) & =S_{0}(x)+\epsilon S_{1}(x),
\end{aligned}
$$

where $u, w, \sigma_{x}, \sigma_{z}$, and $\tau_{x z}$ are the velocities and the stresses caused by the basic flow. $S_{0}(x)$ is the surface trend line, which is the upper boundary for the basic flow, and the second terms on the right-hand sides are the perturbation terms caused by the basal perturbations (9) (Hutter and others, 1981). The basic terms in (9) have an $x$-variation, so they can describe a "realistic" basic flow between the smoothed boundaries $R_{0}(x)$ and $S_{0}(x)$. In the perturbation model the perturbation terms in Equation (10) will be considered to be sinusoidal in due to the harmonic basal perturbation given by Equation (9). this requires the $x$-variation of the basic terms to be small compared to the perturbation terms, which limits the wavelengths in Equation (9) to a length scale not asymptotically large compared with the ice thickness. The resulting perturbation model however yields more "realistic" results by allowing the basic flow a small $x$-dependence instead of using a theoretically more correct basic flow independent of $x$ (Hutter, [ ${ }^{c} 1983$ ]; Reeh and others, in press).

If the representations (10) are substituted into the field-equations (balance laws of mass and momentum, and Glen's flow law given by Equations (1) and (6)), and if the terms of equal powers of $\epsilon$ are collected, the first-order field equations are as follows:

$$
\begin{aligned}
& \frac{\partial u_{1}}{\partial x}+\frac{\partial w_{1}}{\partial z}=0, \\
& \frac{\partial u_{1}}{\partial x}=B F_{2} \quad \frac{1}{2}\left(\sigma_{x 1}-\sigma_{z 1}\right)+B F_{1} \tau_{x z 1}, \\
& \quad \frac{1}{2}\left[\frac{\partial u_{1}}{\partial z}+\frac{\partial w_{1}}{\partial x}\right]=3 B_{3} \tau_{x z 1}+B F_{1} \frac{1}{2}\left(\sigma_{x 1}-\sigma_{z 1}\right), \\
& \frac{\partial \sigma_{x 1}}{\partial x}+\frac{\partial \tau_{x z 1}}{\partial z}=0, \\
& \frac{\partial \sigma_{z 1}}{\partial z}+\frac{\partial \tau_{x z 1}}{\partial x}=0 .
\end{aligned}
$$

$F_{1}, F_{2}$, and $F_{3}$ depend on the basic stresses:

$$
\begin{aligned}
& F_{1}=\left(\sigma_{x 0}-\sigma_{z}\right) \tau_{x z 0}, \\
& F_{2}=\tau_{x z 0}^{2}+\frac{3}{4}\left(\sigma_{x 0}-\sigma_{z 0}\right)^{2}, \\
& F_{3}=\tau_{x z 0}^{2}+\frac{1}{12}\left(\sigma_{x 0}-\sigma_{z 0}\right)^{2},
\end{aligned}
$$

where the basic shear stress $\boldsymbol{T}_{x z 0}$ is determined by Equation (3) and the longitudinal stress deviation $\left(\sigma_{x o}-\sigma_{z 0}\right)$ is modelled as described above.

As to boundary conditions, the velocities are assumed to be zero at the base, the ice temperature being below the pressure-melting point $\left(-13^{\circ} \mathrm{C}\right.$; Gundestrup and Hansen, 1984), and at the surface the stresses must be continuous. Furthermore, the surface must satisfy the conditions of a kinematic surface. Hence, the boundary conditions are:

$$
\begin{aligned}
& \begin{array}{ll}
u=w=0 & \text { at } z=R(x)
\end{array} \\
& \tau_{x z}=\sigma_{x} \frac{\mathrm{dS}}{\mathrm{d} x}, \\
& \sigma_{z}=\sigma_{x}\left(\frac{\mathrm{dS}}{\mathrm{d} x}\right)^{2}, \\
& \text { at } z=S(x) \text {, } \\
& \frac{\mathrm{dS}}{\mathrm{d} x} u-w=a,
\end{aligned}
$$

$a$ being the accumulation rate at Dye 3 .

The first-order boundary conditions for the field equations (11) are derived by substituting Equations (9) 
and (10) into the boundary conditions (12) and approximating them to the conditions at the mean base $R_{0}(x)$ and surface $S_{0}(x)$ by Taylor series expansions. Note that the surface perturbations $S_{1}(x)$ appearing in the approximated boundary conditions are considered as unknown.

The field equations (11) were also used in the modelling by Reeh and others (in press). However in that study $F_{1}$ was neglected, and $F_{2}$ was put approximately equal to $F_{3}$, the depth variation of which was approximated by an exponential variation. In this study the latter, rather rough approximation is avoided and the ice is divided into $M$ layers, in which $F_{2}, F_{3}$, and $B$ are assumed to be constant (Fig. 4). The terms containing $F_{1}$ are still neglected as they are an order of magnitude smaller than the terms containing $F_{2}$ and $F_{3}$ near the base, where $\left(\sigma_{x 0}-\sigma_{z 0}\right) \ll T_{x z 0}$ (Dahl-Jensen, unpublished).
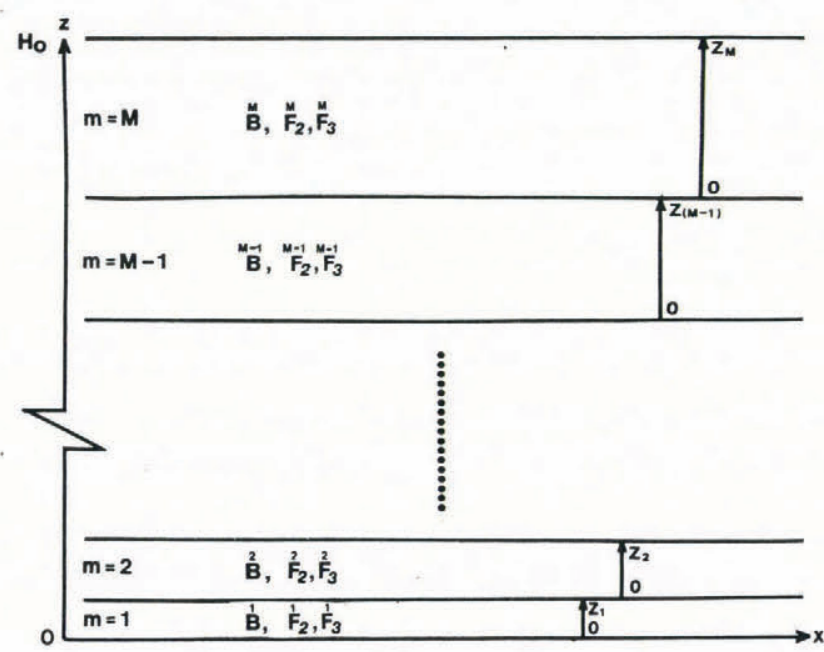

Fig. 4. Definition of the coordinate systems used in the perturbation model.

With these three assumptions the $m$ th layer has the following field equations:

$$
\begin{aligned}
& \frac{\partial u_{1}^{m}}{\partial x}+\frac{\partial w_{1}^{m}}{\partial z}=0, \\
& \frac{\partial u_{1}}{\partial x}=\frac{1}{2}\left(\begin{array}{l}
m m \\
B F_{2}
\end{array}\right]\left[\begin{array}{l}
m \\
\sigma_{x 1}-\sigma_{z 1}
\end{array}\right] \\
& \frac{1}{2}\left[\frac{\partial^{m} u_{1}}{\partial z}+\frac{\partial w_{1}}{\partial x}\right]=3\left[\begin{array}{l}
m m \\
B F_{3}
\end{array}\right]^{m} \tau_{x z 1}^{m}, \\
& \frac{\partial^{m} \sigma_{x 1}}{\partial x}+\frac{\partial^{m} x r_{x 1}}{\partial z}=0, \\
& \frac{\partial_{\sigma_{z 1}}^{m}}{\partial z}+\frac{\partial^{m} \tau_{x z 1}}{\partial x}=0, \quad \text { for } z \in\left[0, Z_{m}\right]
\end{aligned}
$$

These field equations are nearly identical to the field equations for a Newtonian viscous fluid and can be solved accordingly by the use of the stress function (Hutter and others, 1981). The field equations have an analytical solution because $\underset{B F}{m}$, and $\underset{B}{m} F_{3}$ are assumed constant in each layer. It is an advantage to have analytical solutions, still with the use of non-linear rheology. It greatly simplifies the problem, and hence it is more feasible for computer calculations.

As boundary conditions between the layers it is assumed that

$$
\begin{aligned}
& \stackrel{m}{u}_{1}\left(Z_{m}\right)=\stackrel{m+1}{u_{1}}(0), \\
& {\underset{w}{1}}_{1}^{m}\left(Z_{m}\right)={ }_{w_{1}}^{m+1}(0), \\
& {\stackrel{m}{\sigma_{z 1}}}_{\left(Z_{m}\right)}={\stackrel{m+1}{\sigma_{z 1}}(0)}^{m} \\
& {\stackrel{m}{T_{X z 1}}}_{\left(Z_{m}\right)=\boldsymbol{T}_{x z 1}+1}(0), \quad \text { for } m=1, M-1 .
\end{aligned}
$$

The $M$ systems of field equations, and the corresponding boundary conditions, define the first-order boundary-value problem. As the $x$-variation of the first-order solution is entirely caused by the harmonic form of the basal perturbation $\epsilon R_{1}(x)=\epsilon H_{0} \cos \omega x$, the expressions for the resulting perturbations will also be sinusoidal in $x$, with the same frequency. Specifically, the surface perturbation $\epsilon S_{1}(x)$ will be sinusoidal, and with a phase shift $\Phi(\omega)$ relative to the base perturbation:

$\epsilon S_{1}=\epsilon S_{1} \cos \omega x+\epsilon S_{2} \sin \omega x=F(\omega) H_{0} \cos (\omega x-\phi(\omega)$,

where the functions

$$
F(\omega)=\frac{\left[s_{1}^{2}+s_{2}^{2}\right]^{1 / 2}}{H_{0}}
$$

and

$$
\Phi(\omega)=\tan ^{-1}\left(s_{2} / s_{1}\right)
$$

are called the filter function and the phase shift respectively. When used on the basal Fourier series (9), they produce a Fourier series for the surface undulations.

\section{RESULTS}

Calculations of the filter function and the phase shift for the Dye 3 region are shown in Figure 5.

The filter function increases with the wavelength $\lambda$ between 5 and $25 \mathrm{~km}$ (Fig. 5). The phase shifts are close to $-\pi / 2$ for $\lambda>4 \mathrm{~km}$.

\section{Filterfunction, DYE 3}

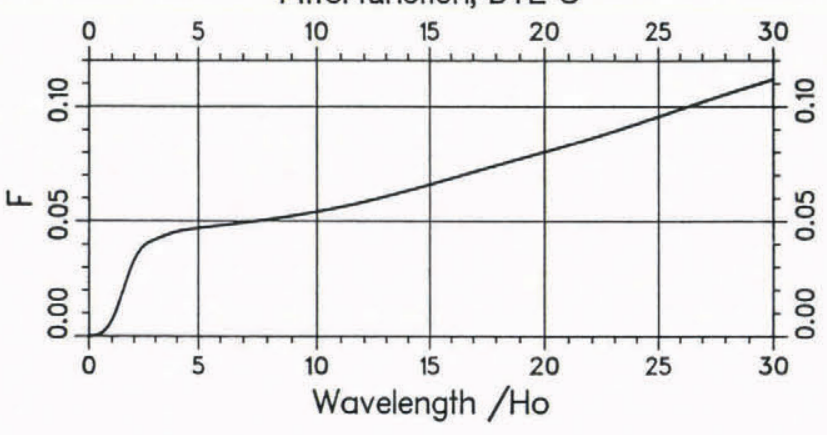

Phaseshift, DYE 3

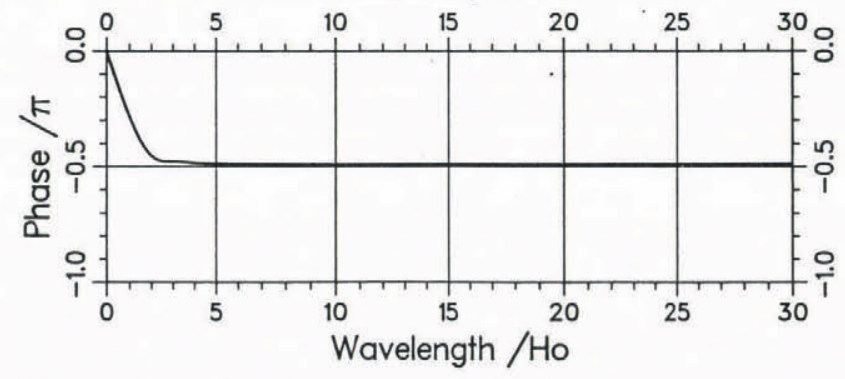

Fig. 5. The filter function and the phase shift calculated by the model for the Dye 3 region. 
a)

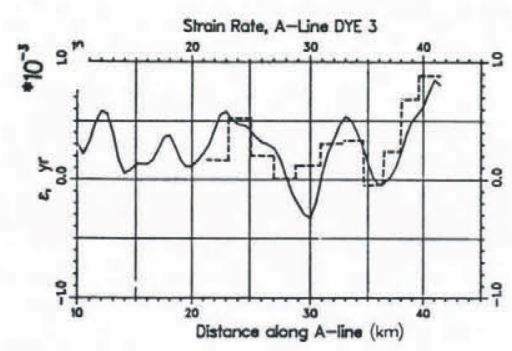

b)

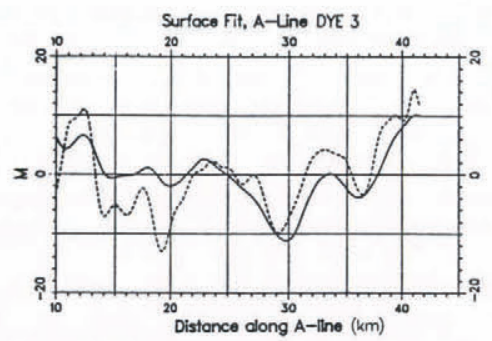

c)

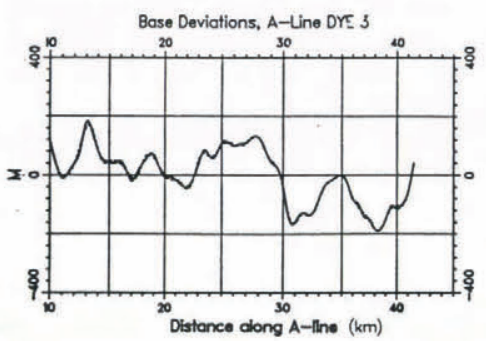

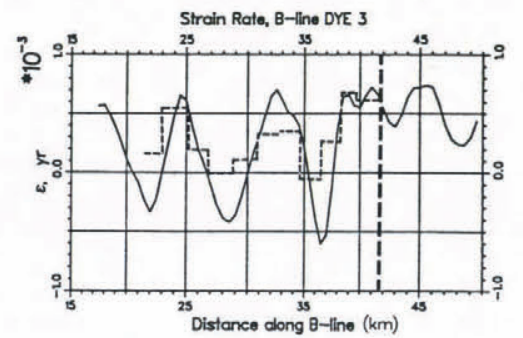
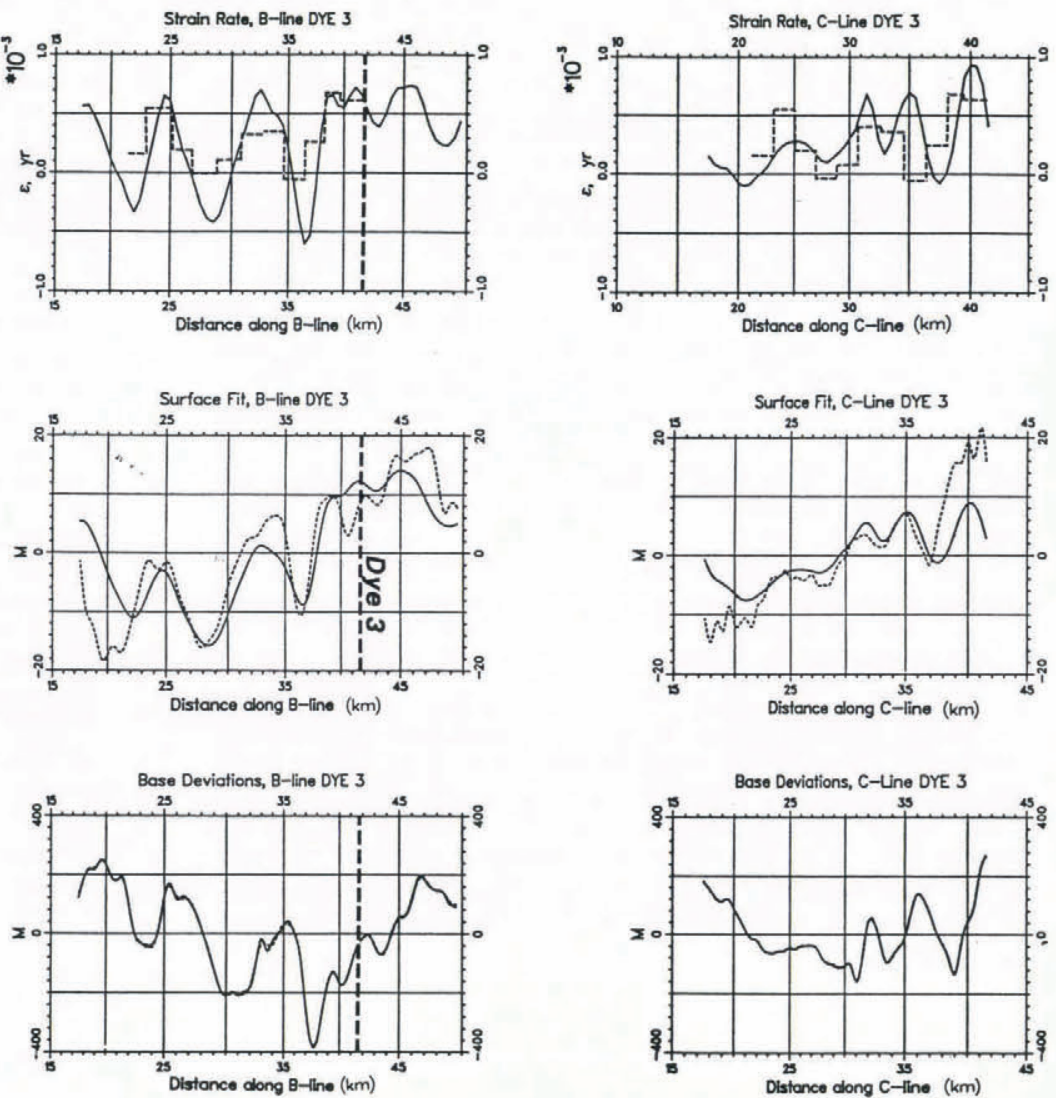

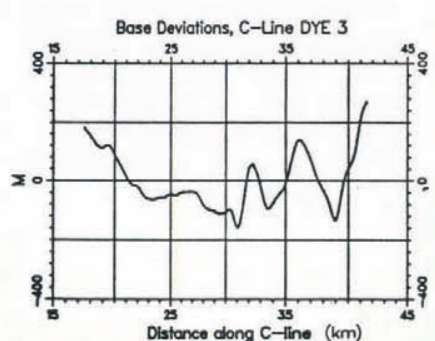

Fig. 6. Comparison of the calculated surface undulations and strain-rates with those observed for the $A, B$, and $C$ lines.

(a) 12-component Fourier representation of the modelled strain-rates (full curves). The dashed step curves are the average strain-rates measured by Whillans and others (1984).

(b) 12-component Fourier representation of the modelled surface undulations (full curves) and the observed undulations (Overgaard and Gundestrup, in press) (dashed curves).

(c) Basal deviations from the trend lines in Figure $2 b$ (full curve). A 12-component Fourier representation of the curves (dashed curves) coincides completely with the full curves.

Comparison with the observed surface deviations (Fig. 6b) shows good agreement for the $\mathrm{A}, \mathrm{B}$, and $\mathrm{C}$ lines in Figure 1. The dominating wavelength of the surface and basal undulations is $8 \mathrm{~km}\left(4 H_{0}\right)$, so with the basal amplitudes being of the order of $100 \mathrm{~m}$ (cf. Fig. 6c), the surface amplitudes are of the order of 4 to $5 \mathrm{~m}$. As the Fourier-resolved bases are non-periodic and have different values at the beginning and the end of the regions considered, disagreement between the calculated and true surface must be expected over the first $4 \mathrm{~km}$ and the last $4 \mathrm{~km}$.

Analyses show that the filter function is very sensitive to the $B$-profile. Using the exponential form of the flow-law parameter, as in the previous model (Reeh and others, in press), the filter-function values become $50 \%$ lower. The disagreement in the previous model is believed to be due to the applied $B$-profile, rather than to non-stationarity, or to the two-dimensional approximation, or to the rather big basal undulations $\left(0.15 H_{\mathrm{o}}\right)$ in the first-order model.

Use of a $B$-profile where the $c$-axis orientation also affects the enhancement factor as suggested by Russell-Head and Budd (1979) gives filter-function values $30 \%$ higher than those observed for the dominating wavelengths.

The calculated surface strain-rates $\partial u / \partial x$ have amplitudes of the order of $3 \times 10^{-4}$ year $^{-1}$, which is of the same order as the mean strain-rates in the Dye 3 region (Whillans and others, 1984). The perturbation terms of the surface strain-rates are in phase with the surface undulations, having a phase shift of $-\pi / 2$ relative to the base. Although the measured strain-rates (step curves in Figure 6a) are only average values over $2 \mathrm{~km}$, the calculated strain-rate amplitudes seem to be too big. This might be expected (in particular for wavelengths smaller than $3 H_{\mathrm{o}}=6 \mathrm{~km}$ ) in view of the approximations in the first-order perturbation theory, which are more serious for calculation of surface strain-rates than for calculation of surface undulations, as will be discussed in a forthcoming paper.

\section{SUMMARY AND CONCLUSIONS}

The flow law parameter derived from the Dye 3 bore-hole-tilting measurements is divided into a temperature-dependent factor and an enhancement factor that depends on other ice parameters. The enhancement factor is equal to unity in the Holocene ice (the upper $1780 \mathrm{~m}$ of the core), and it has a mean value of three in the underlying Pleistocene ice. The high values of the enhancement factor in the Pleistocene ice are believed to be due to the high concentration of dust and other impurities, and to small crystal size. The $c$-axis orientation does not seem to affect the deformation rates.

The dramatic change of the enhancement factor at the Holocene/Pleistocene transition is essential for modelling the present and past flow of the Greenland ice sheet, because the easy-flowing layer of ice has been becoming thinner and thinner, ever since the end of the last glaciation.

The perturbation model described above divides the ice into layers, within which the flow law parameter is assumed to be constant. The perturbation model has analytical solutions in each layer, which limits the 
required computer time. The number of layers can be chosen to agree with the amount of information available regarding the flow law parameter.

The flow law parameter derived from the Dye 3 deep-hole measurements, and the basal topographic observations are used as inputs in the perturbation model to predict the surface profile and the strain-rates. The agreement with the observed surface profiles and strain-rates shows that the applied flow-law parameter profile is realistic.

Analyses show, that the results from the perturbation model are very sensitive to the flow-law parameter used as an input. Beyond being used with a basic flow model, to calculate the age-depth relationship and the flow, the perturbation model can be used on other flow lines where base and surface profiles are known, to estimate the flowlaw parameter iversus depth.

\section{ACKNOWLEDGEMENT}

The Department of Physical Glaciology, Geophysical Institute, have given valuable help and discussions. Lyle Hansen and Niels Gundestrup very kindly provided the data from the logging of the Dye 3 deep hole. This work has been funded by Danish Natural Science Research Council and the European Economic Community, XII Directorate General (Contract CLI.D67.DK.1).

\section{REFERENCES}

Budd, W.F. 1970. Ice flow over bedrock perturbations. Journal of Glaciology, Vol. 9, No. 55, p. 29-48.

Dahl-Jensen, D. Unpublished. Perturbationsmodeller og isens flydeegenskaber ved Dye 3, Syd Grønland. [M. Sc. thesis, University of Copenhagen, 1984.]

Dansgaard, W., and others. 1982. A new Greenland deep ice core, by W. Dansgaard [and 6 others]. Science, Vol. 218, No. 4579, p. 1273-77.

Glen, J.W. 1955. The creep of polycrystalline ice. Proceedings of the Royal Society of London, Ser. A, Vol. 228 , No. 1175 , p. 519-38.

Gundestrup, N.S., and Hansen, B.L. 1984. Bore-hole survey at Dye 3, south Greenland. Journal of Glaciology, Vol. 30, No. 106, p. 282-88.

Hammer, C.U., and others. In press. Continuous impurity analysis along the Dye-3 deep core, by C.U. Hammer, H.B. Clausen, W. Dansgaard, A. Neftel, P. Kristinsdottir, and E. Johnsen. (In Langway, C.C., jr, and others, ed. The Greenland Ice Sheet Program. Edited by C.C. Langway, jr, H. Oeschger, and W. Dansgaard. Washington, D.C., American Geophysical Union. (Geophysical Monograph Series.))

Herron, S.L., and others. In press. Ultrasonic velocities and crystalline anisotropy in the ice core from Dye 3, Greenland, by S.L. Herron, C.C. Langway, jr, and K.A. Brugger. (In Langway, C.C., jr, and others, ed. The Greenland Ice Sheet Program. Edited by C.C. Langway, $j r, H$. Oeschger, and W. Dansgaard. Washington, D.C., American Geophysical Union. (Geophysical Monograph Series.))
Hutter, K. [ $\left.{ }^{c} 1983.\right]$ Theoretical glaciology; material science of ice and the mechanics of glaciers and ice sheets. Dordrecht, etc., D. Reidel Publishing Company; Tokyo, Terra Scientific Publishing Company.

Hutter, K., and others. 1981. First-order stresses and deformations in glaciers and ice sheets, by $\mathrm{K}$. Hutter, F. Legerer, and U. Spring. Journal of Glaciology, Vol. 27 , No. 96 , p. $227-70$.

Johnsen, S.J., and others. 1979. Theory of deformations within ice sheets due to bottom undulations, by S.J. Johnsen, K. Rasmussen, and N. Reeh. Journal of Glaciology, Vol. 24, No. 90, p. 512. [Abstract.]

Nye, J.F. 1959. The motion of ice sheets and glaciers. Journal of Glaciology, Vol. 3, No. 26, p. 493-507.

Overgaard, S., and Gundestrup, N.S. In press. Bedrock topography of the Greenland ice sheet in the Dye 3 area. (In Langway, C.C., jr, and others, ed. The Greenland Ice Sheet Program. Edited by C.C. Langway, $j r, H$. Oeschger, and W. Dansgaard. Washington, D.C. American Geophysical Union. (Geophysical Monograph Series.))

Overgaard, S., and Rasmussen, K. 1979. Study of deformations within ice sheets due to bottom undulations by means of radio echo-sounding. Journal of Glaciology, Vol. 24, No. 90, p. 513. [A bstract.]

Paterson, W.S.B. 1981. The physics of glaciers. Second edition. Oxford, etc., Pergamon Press. (Pergamon International Library.)

Paterson, W.S.B. 1983. Deformation within polar ice sheets; an analysis of the Byrd Station and Camp Century borehole-tilting measurements. Cold Regions Science and Technology, Vol. 8, No. 2, p. 165-79.

Ragle, R.H., and Davis, T.C., jr. 1962. South Greenland traverses. Journal of Glaciology, Vol. 4, No. 31, p 129-31. [Correspondence.]

Rasmussen, K. Unpublished. Isbevaegelse over en undulerende bund. [M.Sc. thesis, University of Copenhagen, 1977.]

Reeh, N., and others. In press. Dating the Dye 3 deep core by flow model calculations, by N. Reeh, S Johnsen, and D. Dahl-Jensen. (In Langway, C.C., jr. and others, ed. The Greenland Ice Sheet Program. Edited by C.C. Langway, jr, H. Oeschger, and W. Dansgaard. Washington, D.C., American Geophysical Union. (Geophysical Monograph Series.))

Russell-Head, D.S., and Budd, W.F. 1979. Ice-sheet flow properties derived from bore-hole shear measurements combined with ice-core studies. Journal of Glaciology, Vol. 24 , No. 90 , p. $117-30$.

Shoji, H., and Langway, C.C., Jr. In press. Mechanical properties of fresh ice core from Dye 3, Greenland. (In Langway, C.C., jr, and others, ed. The Greenland Ice Sheet Program. Edited by C.C. Langway, jr, H. Oeschger, and $W$. Dansgaard. Washington, D.C., American Geophysical Union. (Geophysical Monograph Series.))

Whillans, I.M., and Johnsen, S.F. 1983. Longitudinal variations in glacial flow: theory and test using data from the Byrd Station Strain Network, Antarctica. Journal of Glaciology, Vol. 29, No. 101, p. 78-97.

Whillans, I.M., and others. 1984. Ice flow leading to the deep core hole at Dye 3, Greenland, by I.M. Whillans, K.C. Jezek, A.R. Drew, and N. Gundestrup. Annals of Glaciology, Vol. 5, p. 185-90.

Zwally, H.J., and others. 1983. Surface elevation contours of Greenland and Antarctic ice sheets, by H.J. Zwally, R.A. Bindschadler, A.C. Brenner, T.V Martin, and R.H. Thomas. Journal of Geophysical Research, Vol. 88, No. C3, p. 1589-96. 